\title{
Cytotoxicity of Aqueous Garlic and Ginger Metal Nanoparticles Extracts against Tumor Cell Lines "In Vitro" El-Refai, A. A. ${ }^{1}$; Gehan A. Ghoniem ${ }^{1}$; A. Y. El-Khateeb ${ }^{2}$ and M. M. Hassaan $^{1}$ ${ }^{1}$ Food Industries Department, Faculty of Agriculture, Mansoura University, Egypt \\ ${ }^{2}$ Agriculture Chemistry Department, Faculty of Agriculture, Mansoura University, Egypt
}

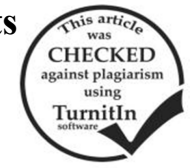

\section{ABSTRACT}

Some minerals were used in nanoparticles green synthesis as a potential application of new technology. Therefore, green synthesis of nanoparticle using silver, zinc, copper and iron metals and its evaluation against anticancer activity, through aqueous extract of garlic (Allium sativum) bulbs and ginger (Zingiber officinale) rhizomes were studied. Total polyphenols and antioxidant activity \% (DPPH) were determined, while, HPLC technique was used to fractionate phenol and flavonoid components. Characterization of silver, copper, iron and zinc nanoparticles for both of garlic and ginger plant extracts were estimated by U.V.-Visible spectroscopy and transmission electron microscopy (TEM). Plant extracts and their nanoparticles were evaluated as in vitro anticancer agents against Caco, HEPG2 and T47D cell lines using different concentrations of (100, 250 and $500 \mu \mathrm{g} / \mathrm{mL}$ ). Obtained results showed that ginger-copper nanoparticles were the most effective anticancer agent in compare with all tested cell lines.

Keywords: Garlic and ginger plants, aqueous extracts, metal NPs green synthesis, TEM characterizations, cancer cell lines.

\section{INTRODUCTION}

Natural foods have long been a major source of cancer treatment, which becoming one of the leading causes of death in this century. However, most research is continuing to develop anti-cancer drugs and chemotherapy strategies. There are at least 250,000 species of plants including more than a thousand anti-cancer plants (Umadevi et al., 2013).

Ginger is the rhizome of the plant (Zingiber officinale Roscoe) which is commonly used as a spice around the world (Larsen et al., 1999). Different dietary factors are the source of many essential compounds used to treat cancer (Khan et al., 2007). The 6-gingrol is the important ingredient extracted from ginger and has anticancer properties (Lee et al., 2008).

Garlic bulbs (Allium sativum) include sulfur components, several enzymes, seventeen amino acids and minerals. Garlic bulbs contain much bioavailable selenium, which is an antioxidant and could be chemopreventive ( $\mathrm{Lu}$ et al., 1996).

The purpose of this research was a trial to prepare and characterize the metals-nanoparticles using aqueous extracts of both bulbs of garlicbubs and ginger rhizomes . The cytotoxicity of the prepared nanomaterials was also evaluated using Caco, Hepg2 and T47D tumor cell lines.

\section{MATERIALS AND METHODS}

\section{Materials \\ 1. Raw materials}

Garlic bulbs and ginger rhizomes were obtained from local market, El-Mansoura city, Egypt.

\section{Chemicals}

Folin-Ciocalteu's phenol reagent was purchased from Fluka, Biochemica, Germany, gallic acid from MB, Biomedical Inc., USA; 2, 2-diphenyl-1-picrylhydrazyl (DPPH) from Aldrich Chemistry, Germany; sodium carbonate from El-Nasr Pharmaceutical Chemicals Company, Egypt; silver nitrate from BDH Chemical Co., England; zinc sulfate from Andenex-Chemie, England; copper sulfate and ferric chloride were purchased from Alpha Chemika, India.

\section{Methods \\ 1. Preparation of samples}

Garlic bulbs and ginger rhizomes were peeled and dried in an oven (Galen Kamp) at $55^{\circ} \mathrm{C}$ for 6 hours in ginger and 10 hours in garlic. Garlic and ginger were oven dried to final moisture content $9.5 \pm 0.3 \%$, then crushed to fine powder using Braun GmbH Grinding (Model, KSM2; Type, 4041), the ground plants powder were separated to be fine enough to pass through sieve size $(75-100 \mu \mathrm{m})$ and stored in cooled refrigerator at $6^{\circ} \mathrm{c}$ for 7 days.

\section{Preparation of aqueous plant extract}

Extraction of both garlic and ginger plants were intended agreeing to the technique termed by Dent $e t$ al. (2013). Accurately $5 \mathrm{~g}$ of plants powder were extracted separately using $100 \mathrm{~mL}$ of deionized water performed at $60^{\circ} \mathrm{C}$ for 30 minutes on a horizontal water bath shaker (Memmert WB14, Germany). Extracted samples were filtered through Whatman no. 1 filter paper (Whatman International Ltd., Kent, UK) using a Büchner funnel and the filtrates were adjusted to $100 \mathrm{~mL}$ in volumetric flasks with appropriate deionized water. The extracts were stored at $-18^{\circ} \mathrm{C}$ till analyses.

\section{Determination of total polyphenols}

The modified method of Folin-Ciocalteu's phenol reagent was used to determine the total polyphenols as the method reported by Blainski et al. (2013). Total phenol contents were expressed as milligram gallic acid equivalent (GAE)/100g based on dry weight.

4. Fractionation and identification of polyphenols for ginger and garlic extracts

Phenolic compounds were fractionated and identified using HPLC assay in Food Technology Institute, Agriculture Research Center, Giza, Egypt; according the process reported by Goupy et al. (1999).

\section{Fractionation and identification of flavonoid} compounds

The flavonoid compounds were fractionated and identified using HPLC assay according to the method reported by Mattila et al. (2000).

\section{Determination of antioxidant activity using DPPH} assay

Antioxidant activity of each sample was determined by its ability to scavenge the investigation 2 , 2-Diphenyl-1-picrylhydrazyl (DPPH) according to the method reported by Li et al., (2015). The DPPH radical 
scavenging ability (RSA) was calculated according to Eq. (1):

$$
\operatorname{RSA}(\%)=\frac{A o-A}{A o} \times 100 \mathrm{Eq} \text {. (1) }
$$

Where: $A_{0}$ is the absorbance of control, and $A$ is the absorbance of sample. Each sample was analyzed in triplicate.

\section{Preparation of metal nanoparticles}

Silver, zinc, copper and iron nanoparticles were ecofriendly synthesized using the method reported by Pattanayak and Nayak (2013), with a slight modification. Aqueous solution of metal salts $(1 \mathrm{mmol})$ such as silver nitrate, zinc sulfate, copper sulfate and ferric chloride $(20 \mathrm{~mL})$ was prepared using deionized water and added to $20 \mathrm{~mL}$ of prepared plant extracts. The obtained nanoparticles were synthesized in an equimolar ratio of $(1: 1)$ of plant extracts to ion solutions. The reaction mixture was kept under stirring for additional 2 hours at room temperature Devasenan et al. (2016). The admixtures were exposed to ultra violetirradiation using reduction factor lamp (Vilber Lourmat6.LC, France) at wave length $(\lambda=254 \mathrm{~nm})$, for 10 minutes according to Supraja et al. (2013).

\section{Instrumental analysis for metals nanoparticles}

The reduction of pure $\mathrm{Ag}+, \mathrm{Zn}++, \mathrm{Cu}++$ and $\mathrm{Fe}+++$ ions and capping of the resulting silver, zinc, copper and iron nanoparticles were monitored according to El-Shahaby et al. (2013), using ATI Unicom UV-Vis Spectrophotometer by recording the ultra violet-visible spectra of the reaction mixture at different wavelengths. The ultra violet-visible spectra of the resulting silver, zinc, copper and iron nanoparticles were recorded in the range of 200-800 nm using ATI Unicom UV-Vis. Spectrophotometer with the aid of ATI Unicom UVVis. vision software V 3.20. The examination was performed at chamber heat by quartz cuvettes $(1 \mathrm{~cm}$ optical path), and the blank was the consistent garlic and ginger extracts.

9. Transmission electron microscope measurements (TEM)

Size, shape, surface area, crystal structure and morphological data of the obtained nanoparticles were characterized using transmission electron microscopy, TEM (JEOL TEM-2100) connected to a CCD camera at an accelerating voltage of $200 \mathrm{kV}$. Each sample of the prepared metal nanoparticles was prepared by involving a suspension of the sample on grids of carbon coated with copper and the solvent was allowed to be evaporated slowly before recording the TEM images. TEM measurements were recorded at the Central Laboratory, Electron Microscope Unit, Faculty of Agriculture, Mansoura University, Mansoura, Egypt.

10. Potential sulforhodamine B (SRB) cell cytotoxicity assay

The cytotoxic potentiality of the extracts and their nanoparticles was done using the procedure reported by Gaidhani et al. (2013). Cells were plated in 96- multi well plate $\left(10^{4}\right.$ cells /well) for 24 hours before treatment with the tested sample to facilitate the attachment of cell line to the plate wall. Each concentration of the water extracts of garlic and ginger and their nanoparticles at levels of $(100,250$ and $500 \mu \mathrm{g} / \mathrm{mL}$ ) which were transferred to the well monolayer cells and incubated with the sample for 48 hours at $37{ }^{\circ} \mathrm{C}$ under carbon dioxide $(5 \%)$ atmosphere. After 48 hours, cells were fixed, washed and stained with Sulfo-rhodamine-B stain. Excess stain was washed with acetic acid and attached stain was recovered with tris-EDTA buffer. The color intensity was recorded in an ELISA reader. The relation between drug concentration and surviving fraction is plotted to get the survival curve of each tumor cell line. The biological evaluation was carried out at Pharmacology Unit, Department of Oncology, National Cancer Institute, Cairo University, Giza, Egypt.

\section{Statistical analysis}

The statistical analysis of the obtained data was determined using the Co-statistical software package (CoStat program 2005), by analyzing the variance (split block, ANOVA). The differences significance between treatment means were determined using the range test of Duncan's multiple at $\mathrm{p}<0.05$ as the significance level (Duncan 1955).

Results and Discussions

\section{Total polyphenols and DPPH antioxidant activity assay}

Phenolic compounds can play an important role as antioxidants and in preserving various foods from damaged by inhibiting or killing harmful microorganisms. Table (1) shows the total polyphenols of different investigated plant samples. It was noticed that ginger extract had the highest amount of total polyphenols (1740.41 mg/ 100gm) and antioxidant activity agent with inhibition of $80.63 \%$. On the other hand, total polyphenol and antioxidant activity were 298.78 (mg/100gm) and 41.84(\%) for garlic extract.

Table 1. Total polyphenols and antioxidant activity of garlic and ginger extracts.

\begin{tabular}{lcc}
\hline Extracts & $\begin{array}{c}\text { Total polyphenols } \\
\text { (mgGAE/100gm) }\end{array}$ & $\begin{array}{c}\text { Antioxidant activity } \\
\text { (DPPH)(\%) }\end{array}$ \\
\hline Garlic & 298.78 & 41.84 \\
Ginger & 1740.41 & 80.63 \\
\hline
\end{tabular}

Maizura et al. (2011), reported that total phenol and antioxidant activity in fresh ginger rhizomes were 101.6 (mg gallic acid equivalent/100gm) and 79 (mg/100gm). On the other hand, total polyphenol (mg/100gm dry weight) in methanolic, aqueous-methanolic and aqueous garlic and ginger extracts were $12.5,27.6$ and 23.9 , respectively, for garlic extracts and 94.8, 87.6 and 67.4, respectively, for ginger extracts. While, the antioxidant activities of these extracts were $54.71,53.8$ and $54 \%$, respectively, for garlic extracts and 43.5, 29.93 and $28.15 \%$, respectively, for ginger extracts Abdou (2011).

2. Fractionation and identification of polyphenols in garlic and ginger extracts

Data in table (2) show the qualitative and quantitative analysis of polyphenols in garlic and ginger extracts by HPLC. It could be noticed that pyrogallol was the predominant identified compound in both of garlic and ginger extracts which recorded 245.01 and $426.64 \mathrm{ppm}$. The second predominant compound in ginger extract was ellagic acid at concentration 155.42 ppm followed by salicylic acid, coumarin, benzoic acid, catechol, e-vanillic acid, isoferulic acid, vanillic acid, catechin, chlorogenic 
acid, ferulic acid and cinnamic acid. It could be noticed that gallic acid in garlic extract had low concentration 0.97 ppm than ginger extract $8.7 \mathrm{ppm}$. Caffeic acid and caffeine were found in ginger extract at concentrations 6.22 and $8.67 \mathrm{ppm}$ which were higher than garlic extract 0.3 and $0.39 \mathrm{ppm}$. Catechol recorded $9.53 \mathrm{ppm}$ for garlic extract, which was lower than ginger extract $18.26 \mathrm{ppm}$. The content of chlorogenic acid was $4.04 \mathrm{ppm}$ for garlic extract, which was found in lower concentration than that of ginger extract $12.85 \mathrm{ppm}$.

Table 2. Fractionation and identification of phenolic compounds in garlic and ginger plants

\begin{tabular}{lcc}
\hline Phenolic & $\begin{array}{c}\text { Ginger } \\
\text { extract } \\
\text { (ppm) }\end{array}$ & $\begin{array}{c}\text { Garlic } \\
\text { extract } \\
\text { (ppm) }\end{array}$ \\
\hline Gallic acid & 8.7 & 0.97 \\
Pyrogallol & 245.01 & 426.64 \\
4-Aminobenzoic acid & 1.38 & 0.51 \\
3-Hydroxytyrosol & 0.84 & 0.16 \\
Protocatechuic acid (PCA) & 4.97 & 4.22 \\
Catechin & 13.39 & 1.81 \\
Chlorogenic acid & 12.85 & 4.04 \\
Catechol & 18.26 & 9.53 \\
Epicatechin & 8.8 & 0.8 \\
Caffeine & 6.22 & 0.39 \\
4-Hydroxybenzoic acid & 9.58 & 0.91 \\
Caffeic acid & 8.67 & 0.3 \\
Vanillic acid & 14.24 & 0.98 \\
p-Coumaric acid & 2.61 & 1.39 \\
Ferulic acid & 12.42 & 2.84 \\
Isoferulic acid & 14.51 & 2.78 \\
Resveratrol & 0.63 & 0.58 \\
Ellagic acid & 155.42 & 14.29 \\
E-Vanillic acid & 15.1 & 1.46 \\
$\alpha$-Coumaric acid & 6.91 & 1.14 \\
Benzoic acid & 28.42 & 39.22 \\
3,4,5-Trimethoxycinnamic acid & 10.32 & 1.22 \\
Coumarin & 36.3 & 1.02 \\
Salicylic acid & 54.09 & 1.77 \\
Cinnamic acid & 11.5 & 0.6 \\
\hline & & \\
\hline
\end{tabular}

The obtained data are less than those reported by Ghoniem et al., (2014), who found that the fractions of ginger rhizomes contained the predominant polyphenols; pyrogallic acid, caffeine, ferulic acid, coumarin, vanillic acid and 4-hydroxybenzoic acid with the concentrations of $4703.8,76.7,77.1,23.8,38.3$ and 80.8 ppm, respectively.

While, the fractions of garlic bulbs contained the predominant polyphenols; pyrogallic acid, chlorogenic acid, synergic, caffeine and ferulic acid 17258.8, 296.6, 128.3, 89.4 and 94.7 ppm, respectively. Furthermore, Abdelfadel et al. (2016), reported that dried ginger rhizomes contain the predominant polyphenols; Pyrogall, Ctechin, Caffeic, Evanillic, Stoluropeinle and Cinnamic in levels of 392, 123, $680.2,553,166$ and $754.4 \mathrm{ppm}$, respectively, for cold extract and 196.6, 57.5, 1600, 503.3, 70.6 and $1710 \mathrm{ppm}$, respectively, for hot extract.

\section{Flavonoid fractions of ginger and garlic extracts}

High performance liquid chromatography (HPLC) was used for qualitative and quantitative analysis of flavonoids compounds in garlic and ginger extracts as represented in Table (3). Twenty-two flavonoid compounds were detected as authentic samples. The predominant flavonoid compound in garlic and ginger extracts was acacetin which recorded 25.2 and $563.36 \mathrm{ppm}$.

Table 3. Fractionation and identification of flavonoids in ginger and garlic extracts.

\begin{tabular}{|c|c|c|}
\hline Flavonoids & $\begin{array}{c}\text { Ginger extract } \\
\text { (ppm) }\end{array}$ & $\begin{array}{c}\text { Garlic extract } \\
(\mathrm{ppm})\end{array}$ \\
\hline $\begin{array}{l}\text { Luteo.6-arabinose } \\
\text { 8-glucose }\end{array}$ & 14.34 & 0.97 \\
\hline $\begin{array}{l}\text { Luteo.6-glucose } \\
8 \text {-arabinose }\end{array}$ & 8.72 & 0.42 \\
\hline $\begin{array}{l}\text { Apig.6-arabinoe } \\
\text { 8-galactose }\end{array}$ & 9.89 & 0.28 \\
\hline $\begin{array}{l}\text { Apig.6-rhamnose } \\
\text { 8-glucose }\end{array}$ & 9.99 & 0.64 \\
\hline $\begin{array}{l}\text { Apig.6-glucose 8- } \\
\text { rhamnose }\end{array}$ & 100.6 & 4.63 \\
\hline Luteo.7-glucose & 1.82 & 0.35 \\
\hline Narengin & 4.26 & 0.44 \\
\hline Rutin & 0.63 & 0.38 \\
\hline Hesperidin & 4.98 & 1.06 \\
\hline $\begin{array}{l}\text { Quercetin 3- } \\
\text { glucoside }\end{array}$ & 1.19 & .. \\
\hline Rosmarinic & 1.64 & 0.31 \\
\hline $\begin{array}{l}\text { Apig. 7-O- } \\
\text { neohespiroside }\end{array}$ & 1.70 & 0.69 \\
\hline $\begin{array}{l}\text { Kaemp. 3,7- } \\
\text { dirhamoside }\end{array}$ & 6.54 & 1.04 \\
\hline Apig.7-glucose & 0.53 & 0.15 \\
\hline Quercetrin & 0.41 & 0.14 \\
\hline Quercetin & 1.77 & 0.13 \\
\hline Naringenin & 2.14 & 1.04 \\
\hline Hespertin & 8.51 & 0.59 \\
\hline Kaempferol & 2.24 & 0.07 \\
\hline Rhamnetin & 6.85 & 0.43 \\
\hline Apigenin & 2.77 & 0.07 \\
\hline Acacetin & 563.36 & 25.2 \\
\hline
\end{tabular}

Flavonoid compounds of garlic extract were found less greatly than those detected in ginger extract. On the other hand, (Miean \& Mohamed, 2001) and (Leighton et al., 1992), claimed that contents of apigenin, quercetin and myricetin in garlic extract were 217, 47 and 693ppm, respectively, while isorhamnetin, kaempferol and luteolin were not detected. These results differed from obtained results, because it was focused that kaempferol and luteolin were detected in garlic extract and their values were 26.39 and $32.53 \mathrm{ppm}$, respectively. Many factor affecting the variation in the previous compounds as, irrigation, fertilization, soil, climate and chemical analysis methods. Ghasemzadeh et al., (2010), identified the flavonoid compounds in two varieties of ginger roots and found that in the first type, Halia bentong was as follows: querectrin $37.5 \%$, rutin $29.0 \%$, catechin $20.0 \%$, epicatechin $36.4 \%$, arginine $32.7 \%$ and amphetamine $48.9 \%$. In the second type, Halia Para that contains quercetrin $25.5 \%$, catechin $45.5 \%$, epicatechin $78.0 \%$, arginine $25.0 \%$ and amphetamine $20.0 \%$. 


\section{Characterizations of nanoparticles \\ 1. Ultra violet visible spectroscopy}

The production of the silver, copper, iron and zinc nanoparticles has been set by measuring the ultra violet visible spectra of the reaction combination. As seeming from (Figures 1 and 2), the absorption peak seemed at about $280 \mathrm{~nm}$ is corresponding to the typical external plasmon resonance of the resulting silver, copper, iron and zinc nanoparticles. The silver, copper, iron and zinc nanoparticles formed employing garlic and ginger extracts were found to be very constant, possibly because of the polyphenolic compounds present in the extract that prevented agglomeration (Figs. 1 and 2). Garlic and ginger extracts are rich source of flavonoids and phenolics. Flavonoids play a vital role in the reduction process for synthesis of silver, copper, iron and zinc nanoparticles (Ghosh et al., 2012), (Egorova and Revina, 2000). Accordingly, the high flavonoids and phenolics content in garlic and ginger water extracts revealed in the phytochemical analysis strongly support the potential of garlic and ginger to bio-shorthand of silver, zinc, copper and iron ions to silver, zinc, copper and iron nanoparticles.

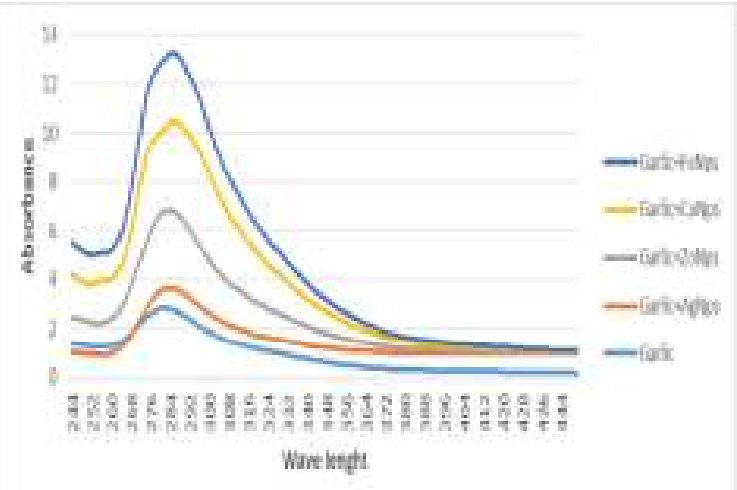

Fig. 1. UV-Vis spectroscopic measurements of garlic and its prepared metal nanoparticles.

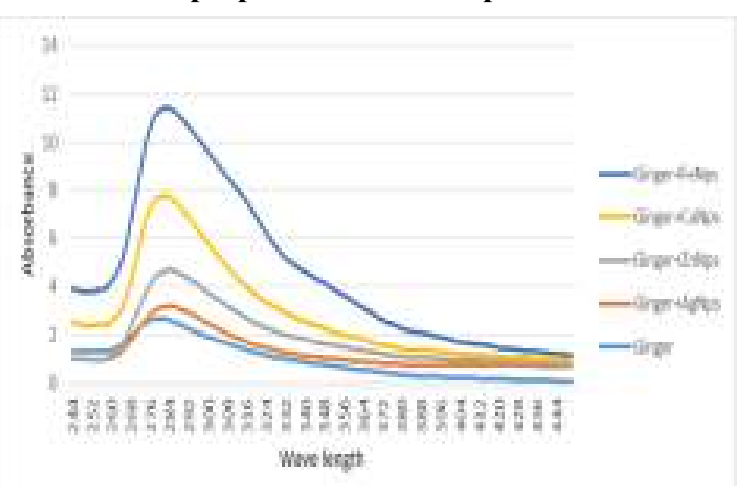

Fig. 2. UV-Vis spectroscopic measurements of ginger and its prepared metal nanoparticles.

\section{Transmission Electron Microscope (TEM)} Characterization for nanoparticles

The $\mathrm{Ag}^{+}, \mathrm{Zn}^{++}, \mathrm{Cu}^{++}$and $\mathrm{Fe}^{+++}$ions with garlic and ginger plant extracts were examined with TEM to confirm the presence of AgNPs, CuNPs, FeNPsand ZnNPs. As shown in Figure (3), the TEM was carried out for the synthesized nanoparticles at $100 \mathrm{~nm}$. The particles size for garlic AgNPs are in the range 13.13$22.69 \mathrm{~nm}$, while the size of ginger AgNPs around 10.10$18.33 \mathrm{~nm}$. The shapes of particles are spherical shape and little numbers are tetragonal shapes. The particles in case of garlic AgNPs are more aggregated more than the particles of ginger AgNPs. Under the given conditions $\left(200 \mathrm{mgL}^{-1} \mathrm{Ag}^{+}, \mathrm{Zn}^{++}, \mathrm{Cu}^{++}\right.$and $\mathrm{Fe}^{+++}$at $\left.20^{\circ} \mathrm{C}\right)$, the smallest AgNPs were formed using the garlic extract. On the other hand, the particles size of garlic CuNPs are around the range14.62-22.80 nm smaller those obtained from ginger CuNPs (14.92-27.41 nm). The ginger CuNPs contains a larger number of small particles size than garlic CuNPs and this is the reason that it gave higher effect on the different cancer cell lines. The particles shape of garlic CuNPs have spherical and tetragonal shapes, while the particles shape of ginger CuNPs are spherical and linear shapes. The particles are more aggregated in case of garlic CuNPs more than ginger CuNPs. The particles size of garlic FeNPs are found in the range $60.30-82.63 \mathrm{~nm}$ with the tetragonal shapes of the particles, while the particles size of ginger FeNPs are in the range of 14.08-21.57 nm with the nearly spherical shape. In general, the particles appear more aggregated in both plants extract, with larger size for ginger FeNPs. Finally, the particle size for garlic or ginger extract with zinc nanoparticle seems to be higher size than the other metals nanoparticles. The garlic ZnNPs size in the range of 99.34-134.57 nm, while the range of ginger ZnNPs 79.88-100.62 nm. The particles are aggregated in tetragonal and hexagonal shapes for garlic ZnNPs and spherical and tetragonal shapes in case of ginger ZnNPs (Fig. 3).

5. Inhibition of cancer cells using nanoparticles (in vitro)

The cytotoxicity of plant extracts of garlic and ginger and their nanoparticles with $\mathrm{Ag}, \mathrm{Zn}, \mathrm{Cu}$ and $\mathrm{Fe}$ metals were evaluated against Caco, HEPG2 and T47D tumor cell lines using different concentrations (100, 250 and $500 \mu \mathrm{g} / \mathrm{mL}$ ). Table (4) show the results of inhibition $\%$ and $\mathrm{IC}_{50}$ values of different tested samples against various cell lines. Ginger and garlic copper nanoparticles had the highest inhibition against T47D tumor cell line (93 and 90\%), while, the synthesized nanoparticles of ginger with $\mathrm{Ag}, \mathrm{Zn}, \mathrm{Cu}$ metals exhibited high activity. While the other tested samples and their nanoparticles have moderate effect to low inhibition percentage. 


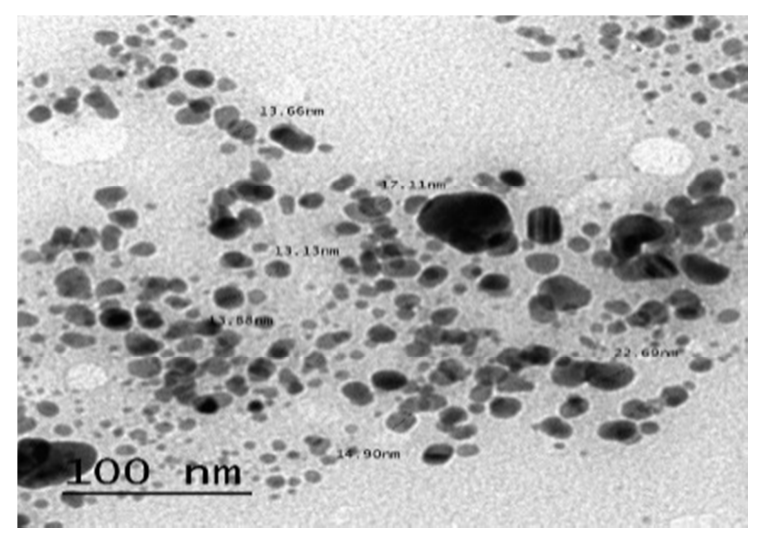

Garlic AgNPs
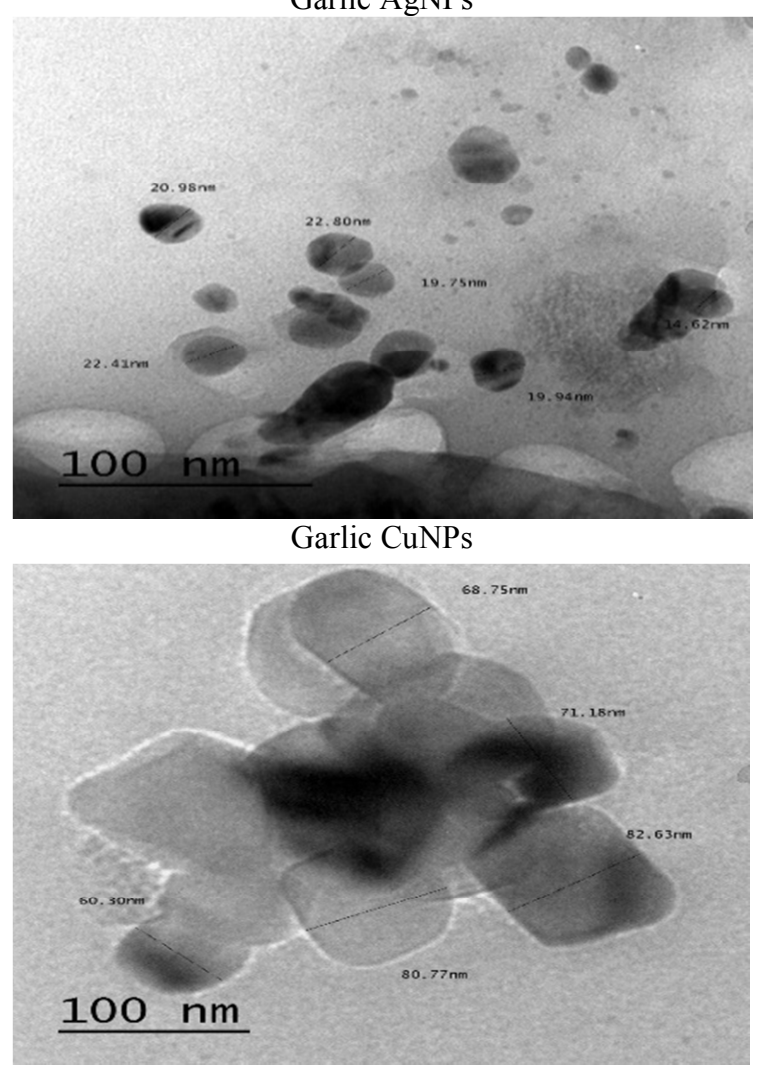

Garlic FeNPs

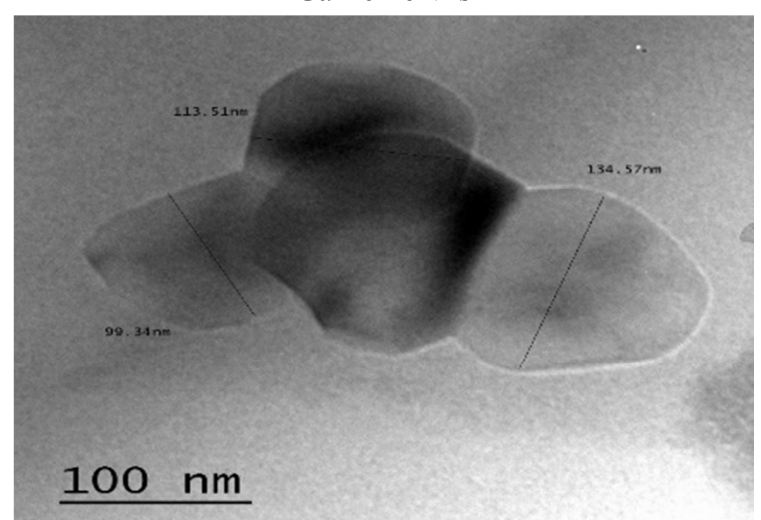

Garlic ZnNPs

Fig. 3. TEM micrographs characterization illustrating the size and morphology of AgNPs, CuNPs, FeNPs and ZnNPs obtained with garlic and ginger extracts at $100 \mathrm{~nm}$.

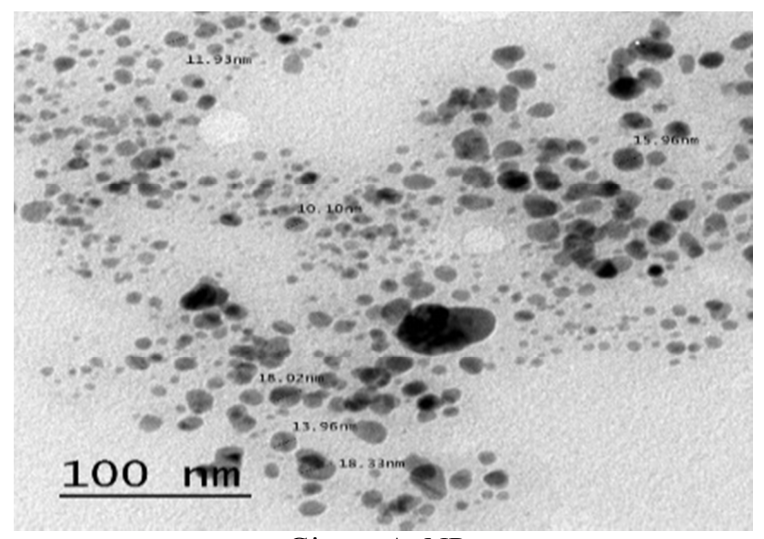

Ginger AgNPs

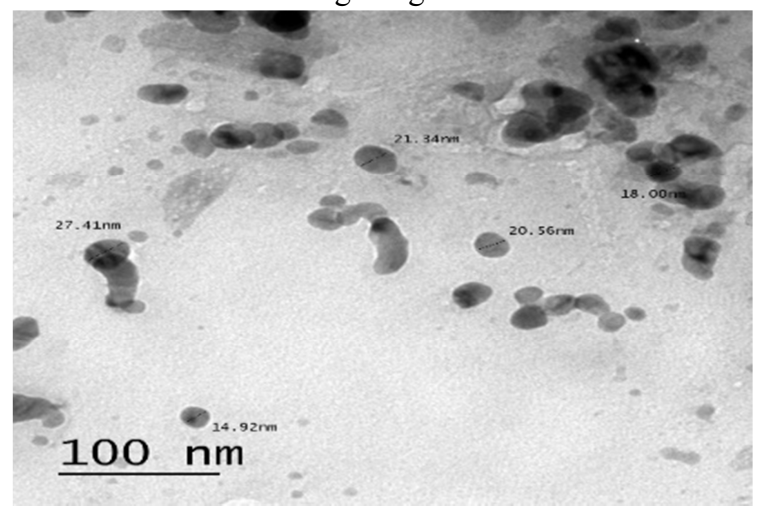

Ginger CuNPs
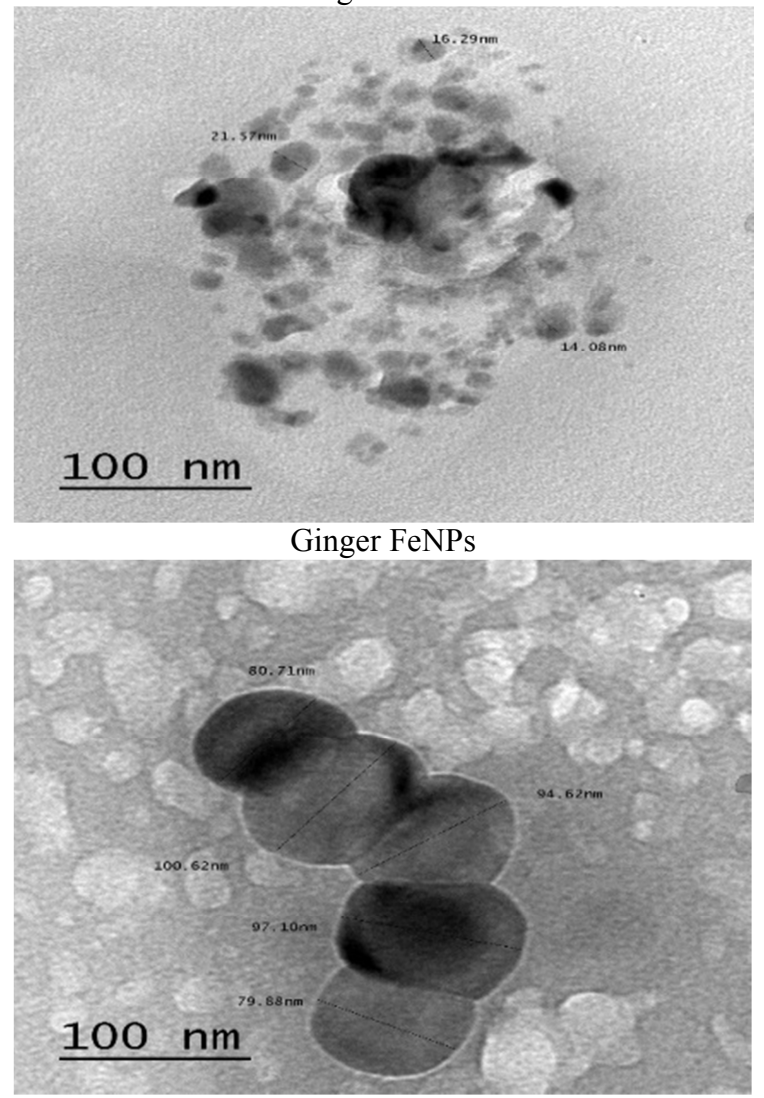

GnigerZnNPs 
El-Refai, A. A. et al.

Table 4. Inhibition $\%$ and $\mathrm{IC}_{50}$ values of plants extracts on different cell lines.

\begin{tabular}{|c|c|c|c|c|c|c|c|}
\hline \multirow{2}{*}{ Sample } & \multirow{2}{*}{ Conc. $\mu \mathrm{g} / \mathrm{mL}$} & \multicolumn{3}{|c|}{ Cancer cells Inhibition \% } & \multicolumn{3}{|c|}{$\mathrm{IC}_{50}$} \\
\hline & & Caco & HEPG2 & T47D & Caco & HEPG2 & T47D \\
\hline Garlic & 100 & $2^{z}$ & $7^{\mathrm{v}}$ & $14^{\mathrm{A}}$ & & & \\
\hline Garlic & 250 & $8^{\mathrm{v}}$ & $12^{\mathrm{u}}$ & $19^{\mathrm{z}}$ & $1558.78^{\mathrm{a}}$ & $1465.76^{\mathrm{a}}$ & $1001.21^{\mathrm{a}}$ \\
\hline Garlic & 500 & $15^{\mathrm{r}}$ & $20^{\mathrm{q}}$ & $30^{\mathrm{x}}$ & & & \\
\hline Garlic + AgNps & 100 & $4^{\mathrm{y}}$ & $13^{\mathrm{t}}$ & $27^{\mathrm{y}}$ & & & \\
\hline Garlic + AgNps & 250 & $7^{\mathrm{w}}$ & $18^{\mathrm{r}}$ & $35^{\mathrm{v}}$ & $1319.39^{b}$ & $1033.4^{\mathrm{b}}$ & $538.05^{\mathrm{b}}$ \\
\hline Garlic + AgNps & 500 & $19^{\mathrm{p}}$ & $29^{\mathrm{m}}$ & $48^{\mathrm{p}}$ & & & \\
\hline Garlic $+\mathrm{ZnNps}$ & 100 & $5^{\mathrm{x}}$ & $17^{\mathrm{s}}$ & $33^{\mathrm{w}}$ & & & \\
\hline Garlic $+\mathrm{ZnNps}$ & 250 & $9^{\mathrm{u}}$ & $21^{\mathrm{p}}$ & $39^{t}$ & $1156.7^{\mathrm{c}}$ & $1008.32^{\mathrm{c}}$ & $501.59^{\mathrm{c}}$ \\
\hline Garlic $+\mathrm{ZnNps}$ & 500 & $22^{\mathrm{n}}$ & $31^{1}$ & $50^{\circ}$ & & & \\
\hline Garlic $+\mathrm{CuNps}$ & 100 & $14^{\mathrm{s}}$ & $35^{\mathrm{i}}$ & $67^{\mathrm{i}}$ & & & \\
\hline Garlic $+\mathrm{CuNps}$ & 250 & $20^{\circ}$ & $40^{\mathrm{g}}$ & $72^{\mathrm{g}}$ & $859.48^{\mathrm{e}}$ & $436.02^{\mathrm{g}}$ & $2.13^{\mathrm{i}}$ \\
\hline Garlic $+\mathrm{CuNps}$ & 500 & $33^{\mathrm{i}}$ & $53^{\mathrm{e}}$ & $90^{\mathrm{b}}$ & & & \\
\hline Garlic $+\mathrm{FeNps}$ & 100 & $2^{\mathrm{z}}$ & $20^{\mathrm{q}}$ & $44^{\mathrm{r}}$ & & & \\
\hline Garlic+FeNps & 250 & $10^{\mathrm{t}}$ & $29^{\mathrm{m}}$ & $57^{\mathrm{m}}$ & $1059.75^{\mathrm{d}}$ & $695.09^{\mathrm{e}}$ & $173.33^{f}$ \\
\hline Garlic + FeNps & 500 & $22^{\mathrm{n}}$ & $40^{\mathrm{g}}$ & $70^{\mathrm{h}}$ & & & \\
\hline Ginger & 100 & $10^{\mathrm{t}}$ & $22^{\circ}$ & $40^{\mathrm{s}}$ & & & \\
\hline Ginger & 250 & $18^{\mathrm{q}}$ & $29^{\mathrm{m}}$ & $48^{\mathrm{p}}$ & $827.81^{\mathrm{f}}$ & $718.79^{d}$ & $296.71^{\mathrm{e}}$ \\
\hline Ginger & 500 & $32^{\mathrm{j}}$ & $40^{\mathrm{g}}$ & $60^{1}$ & & & \\
\hline Ginger $+\mathrm{AgNps}$ & 100 & $25^{\mathrm{m}}$ & $34^{\mathrm{j}}$ & $53^{\mathrm{n}}$ & & & \\
\hline Ginger + AgNps & 250 & $38^{\mathrm{h}}$ & $45^{\mathrm{f}}$ & $66^{\mathrm{j}}$ & $459.41^{\mathrm{i}}$ & $365.52^{\mathrm{h}}$ & $32.04^{\mathrm{g}}$ \\
\hline Ginger + AgNps & 500 & $52^{\mathrm{d}}$ & $57^{\mathrm{d}}$ & $79^{\mathrm{e}}$ & & & \\
\hline Ginger $+\mathrm{ZnNps}$ & 100 & $28^{\mathrm{k}}$ & $37^{\mathrm{h}}$ & $57^{\mathrm{m}}$ & & & \\
\hline Ginger $+\mathrm{ZnNps}$ & 250 & $39^{\mathrm{g}}$ & $45^{\mathrm{f}}$ & $65^{\mathrm{k}}$ & $523.23^{\mathrm{h}}$ & $365.18^{\mathrm{i}}$ & $4.35^{\mathrm{h}}$ \\
\hline Ginger $+\mathrm{ZnNps}$ & 500 & $48^{\mathrm{e}}$ & $57^{\mathrm{d}}$ & $83^{\mathrm{d}}$ & & & \\
\hline Ginger $+\mathrm{CuNps}$ & 100 & $60^{\mathrm{c}}$ & $60^{\mathrm{c}}$ & $77^{\mathrm{f}}$ & & & \\
\hline Ginger $+\mathrm{CuNps}$ & 250 & $63^{\mathrm{b}}$ & $61^{\mathrm{b}}$ & $86^{\mathrm{c}}$ & $5.02^{\mathrm{j}}$ & $1.2^{\mathrm{j}}$ & $1.07^{\mathrm{j}}$ \\
\hline Ginger $+\mathrm{CuNps}$ & 500 & $88^{\mathrm{a}}$ & $84^{\mathrm{a}}$ & $93^{\mathrm{a}}$ & & & \\
\hline Ginger+FeNps & 100 & $15^{\mathrm{r}}$ & $23^{\mathrm{n}}$ & $38^{\mathrm{u}}$ & & & \\
\hline Ginger+FeNps & 250 & $27^{1}$ & $32^{\mathrm{k}}$ & $47^{\mathrm{q}}$ & $579.79^{\mathrm{g}}$ & $583.19^{f}$ & $313.77^{\mathrm{d}}$ \\
\hline Ginger+FeNps & 500 & $44^{\mathrm{f}}$ & $45^{\mathrm{f}}$ & $60^{1}$ & & & \\
\hline $\operatorname{LSD}(p<0.05)$ & & 1.59 & 7.57 & 1.41 & 2.90 & 4.39 & 2.37 \\
\hline
\end{tabular}

Moreover, the tested samples have higher effects on T47D cell line, in which garlic FeNps, ginger CuNps (500 $\mu \mathrm{g} / \mathrm{mL}$ ), garlic CuNps, ginger AgNps and ginger $\mathrm{ZnNps}$ ( 250 and $500 \mu \mathrm{g} / \mathrm{mL}$ ) exhibited the highest anticancer activity. Garlic ZnNps, ginger, ginger FeNps $(500 \mu \mathrm{g} / \mathrm{mL})$, garlic FeNps $(250 \mu \mathrm{g} / \mathrm{mL})$ and garlic CuNps, ginger AgNps and ginger $\mathrm{ZnNps}(100 \mu \mathrm{g} / \mathrm{mL})$ samples have good anticancer activity against T47D cell line. From the obtained $\mathrm{IC}_{50}$ values, it was found that ginger CuNps is the most effective sample against different cell lines at $(500 \mu \mathrm{g} / \mathrm{mL})$, in addition to garlic CuNps and ginger ZnNps samples against T47D cell line.

The inhibition percentage of ginger extract was higher than that of garlic extract because the total polyphenols and antioxidant activity of ginger was higher than those of garlic extract (Table, 4). Nanoparticles loaded with both garlic and ginger aqueous extracts have different effects on inhibiting these cancer cells. Copper nanoparticles had the strongest inhibition effect in both plant extracts followed by silver and zinc then iron and control group.

The obtained data are in agreement with those reported by Shafagh et al. (2015), who found that copper oxide nanoparticles (CuO-NPs) showed selective cytotoxicity towards K562 cell line. This compound is potentially a good anti-cancer drug since it does not kill healthy cells. The CuO-NPs induction of apoptosis was mediated through the reactive oxygen species (ROS) production in cancer cells. Dulta et al. (2017), reported that the metals like silver, gold, iron, zinc and copper had been routinely used for the synthesis of nanoparticles. Nanoparticles have received much attention recently due to their use in cancer therapy. Studies have shown that different metal oxide nanoparticles induced cytotoxicity in cancer cells, but not in normal cells.

As shown in Figures 4-5, the strongest effect of aqueous extracts on different tumor cells was marked on the T47D cell lines followed by HEPG2 and Caco 2 cell lines. 
Other results reported that increase concentrations of ginger extract led to increasing of the percentage inhibition of T47D cell growth. At a concentration of $62.5(\mu \mathrm{g} / \mathrm{mL})$, red ginger rhizome extract inhibited the growth of T47D cells to $32 \%$ Ekowati et al. (2011). Nakagawa et al. (2011), studied the6 diallyl disulfide may be a useful anticancer agent for management of human breast cancer.

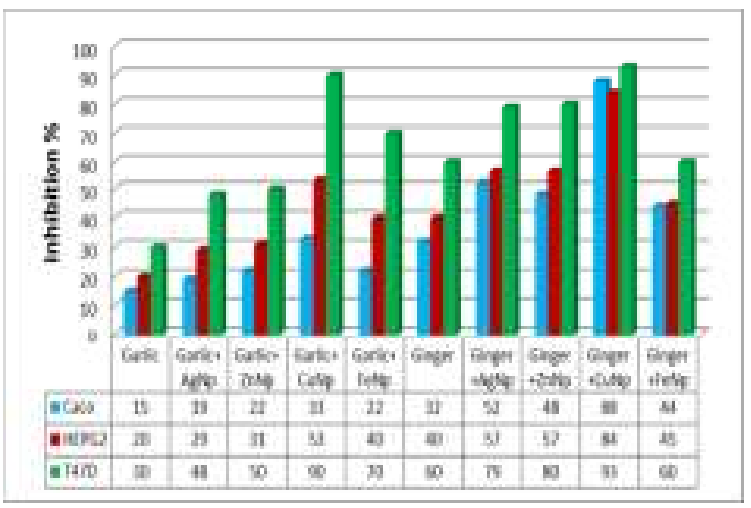

Fig. 4. Inhibition \% values of each plant extracts and their nanomaterials against different tumor cell lines.

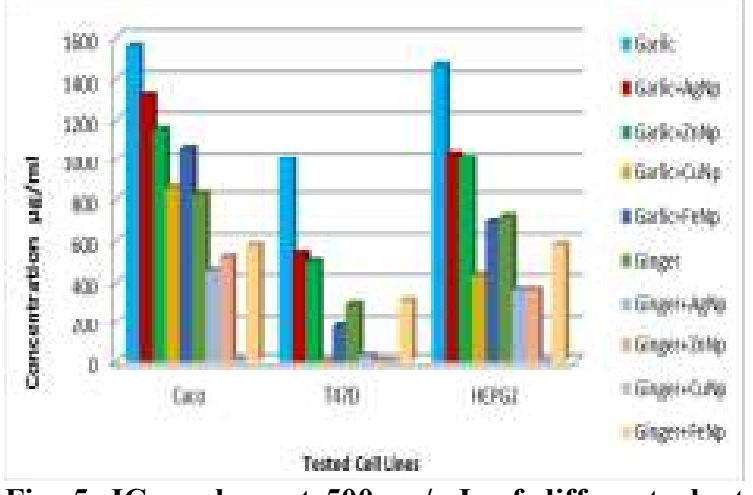

Fig. 5. $\mathrm{IC}_{50}$ values at $500 \mu \mathrm{g} / \mathrm{mL}$ of different plant extracts and their nanomaterials against each of Caco, HEPG2 and T47D tumor cell lines.

\section{CONCLUSION}

Finally, it could be concluded that the green synthesis of nano-metals using natural materials were more safe and easier to prepare. The effectiveness of aqueous garlic and ginger plant extracts in the rapid synthesis of nanoparticles due to their bioactive components that have antioxidant activity played an important role as anticancer agents and could be used as a safe effective sources as a highly anticarcinogenic effects in vitro on tumor cell lines.

\section{REFERENCES}

Abdelfadel, M. M., Khalaf, H.H., Sharoba, A. M. and Assous, M.T.M. (2016). Effect of extraction methods on antioxidant and antimicrobial activities of some spices and herbs extracts. J. Food Technol. Nutr. Sci. 1(1), 1-14.http:// cresco publications .org/ pdf/ jftns/ JFTNS-1-002.pdf

Abdou, H. M. (2011). Comparative antioxidant activity study of some edible plants used spices in Egypt. J Am Sci. 7(1), 1118-1122.
Blainski, A., Lopes, G. C.and De Mello, J. C. P. (2013). Application and analysis of the FolinCiocalteu method for the determination of the total phenolic content from Limonium Brasiliense L. Molecules, 18 (6), 6852-6865.

CoStat program, Version 6.311 (2005). CoHort Software, 798 Light houseAve. PMB 320, Monterey, CA, 3940, USA.

Dent, M., Dragović-Uzelac, V., Penić, M., Brnčić, M., Bosiljkov, T. and Levaj, B.(2013). The effect of extraction solvents, temperature and time on the composition and mass fraction of polyphenols in dalmatian wild sage (Salvia OfficinalisL.)extracts. Polyphenols from dalmatian wild sage.Food Technol. Biotechnol. 51(1), 84-91.

Devasenan, S., Beevi, N. H. and Jayanthi, S. S. (2016). Green synthesis and characterization of zinc nanoparticle usingandrographispaniculata leaf extract. Int J Pharm Sci Rev Res. 39(1),243-247.

Dulta, K., Chauhan, P. K., Kour, J. and Virk, A. K. (2017). Recent trend of plant mediated nanoparticles in cancer treatment: A review. Int $J$ Biol Pharm Appl Sci. (IJBPAS), 6(1), 1-19.

Duncan, D. (1955). Multiply range and multiple F test. Biometrics 11, 1-42.

Egorova E. M. and Revina A. A. (2000). Synthesis of metallic nanoparticles in reverse micelles in the presence of quercetin. Colloids Surf A Physicochem Eng Asp 168: 87-96.

Ekowati, H., Septiyaningsih, S. and Harwoko, H. (2011). An extract of Zingiber officinale and piper retrofractum combination and its effect to cancer cell line. Indonesian $J$ Cancer Chemoprevention, 2(1), 173-181.

El-Shahaby, O.,El-Zayat, M.,Salih, E.,El-Sherbiny, I. M. and Reicha, F. M. (2013). Evaluation of antimicrobial activity of water infusion plant-mediated silver nanoparticles. J NanomedNanotechol4, 178. doi:10.4172/2157-7439.1000178

Gaidhani, S. N.,Singh, A., Kumari, S., Lavekar, G. S., Juvekar, A. S., Sen, S.andPadhi, M. M. (2013). Evaluation of some plant extracts for standardization and anticancer activity. Indian $J$ Traditional Knowledge, 12(4), 682-687.

Ghasemzadeh, A., Jaafar, H. Z. E. andRahmat, A. (2010). Identification and concentration of some flavonoid components in malaysian young ginger (Zingiber officinale Roscoe) varieties by a high performance liquid chromatography method. Molecules, 15, 62316243; doi:10.3390/molecules15096231

Ghosh S, Patil S, Ahire M, Kitture R, Kale S, (2012). Synthesis of silver nanoparticles using Dioscorea bulbifera tuber extract and evalution of its synergistic potential in combination with antimicrobial agents. Int J Nanomedicine. 7: 483-496.

Goneim, G. A., Hussien, M. A., Soliman, G. Z. A. and Essia, A. S. (2014). Biological evaluation of ginger rhizomes, and garlic bulbs extracts. J. Food and Dairy Sci. Mansoura University, 5(12),871-889. 
Goupy, P., Hugues, M., Biovin, P. and Amiot, M. J. (1999). Antioxidant composition and activity of barley (Hordeum vulgare) and malt extracts and isolated phenolic compounds. J. Sci. Food Agric, 79 (12), 1625-1634.

Khan, N., Afaq, F. and Mukhtar, H. (2007). Apoptosis by dietary factors: the suicide solution for delaying cancer growth. Carcinogenesis28 (2), 233 - 239. doi:10.1093/carcin/bgl243.

Larsen, K., Ibrahim, H., Khaw, S. H. and Saw, L. G. 1999. In Gingers of Peninsular Malaysia and Singapore. Kota Kinabalu: Natural History Publications (Borneo), 135 pp.

Lee, S.-H., Cekanova, M. and Baek, S. J. (2008). Multiple mechanisms are involved in6-gingerol-induced cell growth arrest and apoptosis in human colorectal cancer cells. Molecular Carcinogenesis47,197-208.

Leighton, T., Ginther, C., Fluss, L., Harter, W. K., Cansado, J. and Notaro, V. Huang, M.T., Ho, C. T. and Lee, C. Y. (1992). Phenolic compounds from food and their effect on health. American Chemical Society Symp. Ser., 507, 220-238.

Li, J., Fan, S., Qiu, Z., Li, C. and Nie, S. (2015). Total flavonoids content, antioxidant and antimicrobial activities of extracts from Mosla chinensis Maxim. cv. Jiangxiangru. LWT - Food Sci. Technol., 64, 1022-1027.

Lu, J., Pei, H., I., C., Lisk, D. J., Ganther, H. and Thompson, H. J. (1996). Effect on an aqueous extract of selenium- enriched garlic on in vitro markers and in vivo efficacy in cancer prevention. Carcinogenesis .17(9), 1903-7.

Maizura, M., Aminah, A. and Wan Aida, W. M. (2011). Total phenolic content and antioxidant activity of kesum (Polygonum minus), ginger (Zingiber officinale) and turmeric (Curcuma longa) extract. Int Food Res J.18, 529-534.
Mattila, P., Astola, J. and Kumpulainen, J. (2000). Determination of flavonoids in plant material by HPLC with diode- array detections. J. Agric. Food Chem. 48, 5834-5841.

Miean, K. H. and Mohamed, S. (2001). Flavonoid (Myricetin, Quercetin, Kaempferol, Luteolin, and Apigenin) Content of Edible Tropical Plants J. Agric. Food Chem.49(6), 3106-3112. doi: $10.1021 / \mathrm{jf000892m}$

Nakagawa, H., Tsuta, K., Kiuchi, K., Senzaki, H., Tanaka, K., Hioki, K. and Tsubura, A. (2001). Growth inhibitory effects of diallyl disulfide on human breast cancer cell lines. Carcinogenesis22(6),891-0897.

Pattanayak, M. and Nayak, P. L. (2013). Ecofriendly green synthesis of iron nanoparticles from various plants and spices extract. Int. J. Plant, Animal and Environmental Sci., 3(1), 68-78.

Sajid, M., Butt, M. S., Shehzad, A. and Tanweer, S. (2014). Chemical and mineral analysis of garlic: A golden herb. Pak. J. Food Sci. 24(1), 108-110.

Shafagh, M., Rahmani, F. and Delirezh, N. (2015). CuO Nanoparticles induce cytotoxicity and apoptosis in human K562 cancer cell line via mitochondrial pathway, through reactive oxygen species and P53. Iran J Basic Med Sci18(10), 993-1000.

Supraja, S., Mohammed Ali, S., Chakravarthy, N., Jayaprakash Priya, A., Sagadevan, E., Kasinathan, M. K., Sindhu, S. and Arumugam, P. (2013). Green synthesis of silver nanoparticles from Cynodon dactylon leaf extract. Int. J. Chem. Tech, 5(1), 271-277.

Umadevi, M., Kumar, K. P. S., Bhowmik, D., and Duraivel, S. (2013). Traditionally used anticancer herbs in India.J Med Plants Studies, 1(3), 56-74.

\footnotetext{
تم استخدام الفضة ،النحاس ،الزنك و الحديد كجزيئات نانوية بطريقة التخليق الحيوي في تقدير نشاط الخلايا السرطانية باستخدام

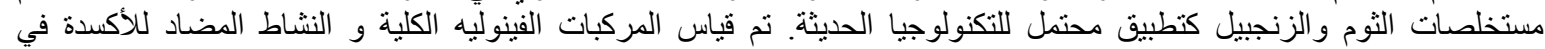

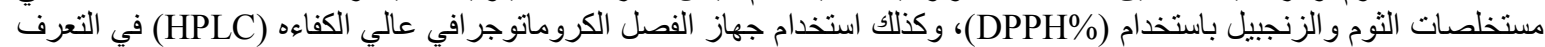

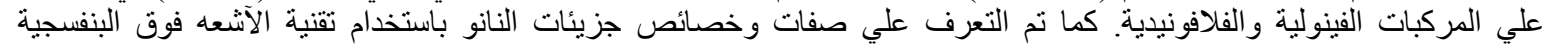

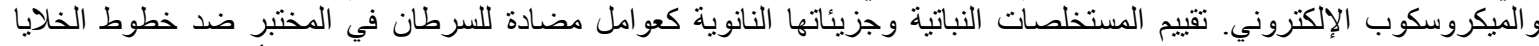

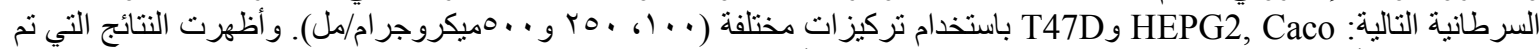
الحصول عليها أن الجسيمات النانوية للزنجبيل مع النحاس كانت أكثر فعالية كعامل مضاد للسرطان مقارنة مع الخلايا المختبره الاخري تحت الدراسة.
} 